\title{
Electronic government public value of public institutions in Jordan
}

\author{
Hasan Alhanatleh $^{a^{*}, \text { Khaled Aboalganam}^{a} \text { and Hussain Awad }}{ }^{\mathrm{a}}$
}

\begin{tabular}{l}
${ }^{a}$ Amman Arab University, Jordan \\
\hline C H R O N I C L E \\
\hline Article history: \\
Received: June 28, 2021 \\
Received in revised format: Sep- \\
tember 28, 2021 \\
Accepted: October 28, 2021 \\
Available online: October 28, \\
2021 \\
\hline Keywords: \\
Public value \\
IS success model \\
e-government \\
e-government public value \\
Jordan
\end{tabular}

\section{A B S T R A C T}

\begin{abstract}
Substantially, the theory of e-government public value (PV-EGOV) has been treated as a hot topic to be explored insightfully. This research comes to be considered as the launching point to empirically evaluate the creation of PV-EGOV in Jordan. The main aim of this research is to investigate the factors affecting the PV-EGOV in the context of Jordan. Information System Success Model (IS success model) was selected to determine the factors affecting the e-government public value in Jordan through the quality factors (system, information, and service) and their role in citizens' intention in use and satisfaction of the e-government. The structural Equation Model (SEM) approach was harnessed to obtain the results. The results indicated that the most critical determinant factor that affected the PV-EGOV was service quality. The current article has theoretical and practical implications for public institutions in Jordan. The future work trends are established in their specific section of this article.
\end{abstract}

\section{Introduction}

The inclusive development of Information communication technologies (ICTs) has rapidly provided several features in different sectors (private institutions, customers, and public institutions). However, getting a better understanding of government institutions' clients is considered as a primary key to qualify the public institutions to optimally introduce their e-government services (Sharma et al., 2013; Alzghoul, 2013; Khaddam et al., 2021). According to Heeks, 2008, PV-EGOV is generated through successfully meeting the citizens' requirements by public institutions. Citizens' requirements are instituted to gain the PV-EGOV through many attributes which are ease of public services accessibility, facility to information accessibility, free of distance constraint, and reduce time and cost. Even though little prior studies have assessed the success of egovernment, the technology of e-government has motivated the related specialists to focus on maximizing the value of egovernment, exploring citizens' perspectives, and success factors. According to Sterrenberg, (2016), the greatest number of research that has been discussed on e-government technology were case studies or systematic review perspectives. Scott et al., (2016) suggested that generating the PV-EGOV technology from citizens is considered a critical determinant for the success of this technology. However, Twizeyimana and Andersson (2019), have asserted that the work under the framework of public value on the e-government domain is limited in literature; specifically, in developing countries like Jordan. Through their study, the authors have declared that there is a need for conducting wide research in these countries related to the public value scope of e-government, the study has also revealed that there are just seven studies about creating PV-EGOV in these countries. Therefore, the lack of conducting research related to the PV-EGOV has paid attention of researchers, specialists, and practitioners to identify the success dimensions of the public value in e-government scope from users' perspective (Sami et

* Corresponding author.

E-mail address: h.hanatleh@aau.edu.jo (H. Alhanatleh)

(C) 2022 by the authors; licensee Growing Science, Canada. doi: $10.5267 /$ j.ijdns.2021.10.007 
al., 2018, Li et al., 2017; Pang et al., 2014). Thus, there is a scarcity of theoretical baseline that assists to empirically disclose the dimensions affecting public value, adoption, and usage of e-government (Abu-Shanab \& Harb, 2019; Li et al., 2017). However, there is a scarcity of conducted studies related to PV-EGOV. Consequently, this study will embark to present assistance for researchers, specialists, and practitioners in the e-government context to empirically explore the potential determinants of the creation of the PV-EGOV in Jordan context.

The major target of this research is to provide an exploration and evaluation of the potential factors that influence the PVEGOV in Jordan through employing the IS success model. Many contributions will be offered within the current research. Firstly, an inclusive review from literature about the PV-EGOV concept and e-government evaluation in Jordan. Secondly, conducting the first empirical research relates to PV-EGOV within Jordan. Thirdly, testing the update IS success model of PV-EGOV from citizens' perspective in Jordan to identify the influential dimensions of PV-EGOV within the Jordan context. Finally, filling the gap in literature relevant to the idiom of PV-EGOV empirically; and presenting an alternative solution to solve Jordan's e-government challenges through the outcomes of our research and its managerial implications in terms of the public value of citizens in Jordan.

\section{Theoretical Background and Developed Hypothesizes}

\section{1. $P V-E G O V$}

Throughout literature, there are many different definitions of e-government and public value that discuss these idioms from various standpoints (Solli-Sæther, 2010). However, we took the following definitions into consideration to serve the nature of current research. ADB (2003) has viewed the public value as eligible, efficient, and desirable services that present to citizens from public institutions to fulfill granulated strategic consequences; E-government is the capability of public institutions to empower the ICTs to serve business functions and interact with public and businesses through support of Internet technology and electronic channels (Almarabeh \& AbuAli, 2010).

It has been argued that the target of public institutions should be shaped to achieve the forming of public value which leads to public institutions' requirements and desires of target citizens (Harrison et al., 2012). In the e-government scope, the idiom of public value might be in line with the capability of e-government technology to furnish boosted efficiency in the government sector, boosted citizens' services, and boosted values of social (Twizeyimana \& Andersson, 2019). According to Panagiota (2020), the public value is generated depending on the directions and decisions of institutions of public service in the way of provided services, the method of specifying resources to reach the particular outcomes, strategic planning execution, and sophisticated operations convenient with the value of public. By way of this study, the author has classified three critical issues that institutions should take into their consideration if institutions have a willingness for creating public value for the public. The first addressed issue is that the providers (Internal or external) of services have an impact on the creation of public value. The second important issue is that the prospect of citizen participation in the shape and present services must be taken into consideration. The last critical issue is that the role of organizations' employees must industriously be considered.

Ha (2016) proposed that the e-government public value might be constituted on the following dimension constituting the services for the public, accomplishing the target results, aggrandizement of trust, and efficiency of public institutions. Accordingly, empirical results in Vietnam country indicated that the PV-EGOV in Vietnam was evaluated through the public institutions effectiveness, introduction of the public services; and the trust and transparency of Vietnam's e-government.

\subsection{E-government Evaluation in Jordan}

Depending on the theory of reasoned action (TRA), Abu-Shanab, (2021) performed research to explore the moderation role of demographic characteristics on Jordan's e-government. It has suggested that trust factor, perceived usefulness factor, perceived ease of use factor, and subjective norms factor have a significant effect on citizens' behavioral intentions in Jordan. Based on this suggested framework, the results indicated that these antecedents' variables had an affirmative and positive impact on citizens' behavioral intentions in Jordan, it has also been revealed that age and education had a moderating role between the antecedents' variables and citizens' behavioral intentions in Jordan. By suggesting and testing a new model (egovernment adoption recommendation model (EGARM)), Mensah, Luo and Abu-Shanab, (2021) conducted valuable research to study and identify determinants affecting the e-government adoption from citizens' perspective in Jordan. The outcomes of this research indicated that the adoption of e-government in Jordan was positively affected by the trust factor and the intention to use factors with their antecedents (IQ, accessibility, accountability, and empowerment). Nawafleh, (2018) carried out a theoretical framework to explore the second phase of the adoption of e-government in Jordan. According to the author, prior research has been conducted to investigate the dimensions affecting attitude toward the first phase of e-government adoption in Jordan through the e-government website. For purposing of continuous utilization of Jordan's e-government, the author suggested that there are five dimensions that impact the sustainability of the e-government usage in Jordan and developing countries which are citizens' digital literacy, marketing efficiency of e-service for the public, the quality of presented e-service, mandatory e-service usage and staff aid for citizens. According to Alabdallat (2020), there are three types of e-government services which are compulsory, optional, and tangible-optional. However, the e-government system in Jordan presents a big deal of e-services for its public through Jordan's e-government website. 
To the best of the authors' knowledge, all studies have discussed e-government technology in Jordan from different perspectives such as acceptance technology, the first and second face of adoption, proposed theoretical framework, and analysis of the e-government characteristics. However, PV-EGOV in the Jordan context is still not confirmed.

\subsection{Developed Research model}

This section will illustrate how the authors have sophisticated the PV-EGOV model from the previous studies.

\subsubsection{PV-EGOV}

In accordance with (DeLone \& McLean 2003), the PV-EGOV simulates the concept of the net benefits of IS focusing on achieving the public value objectives which are effectiveness of the presented service form public institutions, efficiency of presented service form public institutions and enhance social value (Bryson et al., 2014; Scott et al., 2016). Consequently, our research simulates previous studies to achieve these three purposes of public value (effectiveness, efficiency and social value) and to evaluate the e-government project in Jordan from the standpoint of citizens.

\subsubsection{Information System Success Model}

Updated IS success model has substantially been evaluated the ICTs domain that investigates the net benefit of any kind of IS applications by testing the role of quality factors (Information, system, and services) on the net benefit of IS applications with the mediation role of IS use and user's satisfaction dimensions (Alhanatleh, 2020; Nkanata, 2019; DeLone \& McLean, 2003). The updated IS model has also been employed to evaluate the success of e-government systems and PV-EGOV (Agbabiaka, 2018; Stefanovic et al., 2016). In terms of quality factors, System Quality (SQ) dimension of the e-government project aims at representing the e-government system depending on characteristics of the e-government system such as ease of use, user-friendly, and usability (Wang \& Liao 2008; DeLone \& McLean, 2003; Wang et al., 2007). In addition to independent variables, Information Quality (IQ) dimension is known as the key of IS quality outputs defined by various features of information which are; Precise, Up-to-date, sufficient, reliable, and useful (DeLone \& McLean 2003; Petter et al., 2013). Lastly, Service Quality (SVQ) dimension of e-government endeavors at measuring the level of SVQ presented by employees of IS based on several measures of e-government system such employee's readiness to supply appropriate service, secure transactions under e-government system, available at any time to users, developing of e-government system employees and upholding the users' requirements Petter et al. (2013). In the context of e-government, quality factors consider as a fundamental key to determine the Citizens' Satisfaction (CS) and Citizens' Intention to Use (CIU) factors of the e-government system (Idoughi, \& Abdelhakim, 2018; Mirchandani et al., 2018).

CIU considers as the level and method in which staff uses the capacities of the e-government technology, this dimension gauges the demeanor of the e-government users and their belief relying on e-government reliance, recurrence of e-government use, and the propensity of e-government system usability in the future Petter et al. (2013). CS dimension is defined as a comprehensive opinion of users and their judgment about the e-government technology (McLean \& McLean, 1992; Wang \& Wang, 2009), it evaluates the users' behavior of e-government technology depending on several attributes such: perceived benefit, meeting anticipations, valuable to utilize the e-government technology and taking it as a tool for routine processes. In the context of e-government, CIU and CS factors are considered as a fundamental key to determine the net benefit and the PV-EGOV system Suh et al. (2017). The demographic variables might influence the CIU dimension of e-government (Nam, 2014; Stefanovic, 2016). In the current study, the demographic variables could have an affirmative and significant effect on $\mathrm{CIU}$ of the e-government project in Jordan. According to the above explanation, the IS success model is considered a strong construct to evaluate the net benefit of IS and the creation of PV-EGOV. Thus, the hypotheses of the current study about the creation of PV-EGOV in Jordan are developed as follows:

$\mathbf{H}_{1}$ : CIU of the e-government system dimension will be affirmatively and significantly influenced by the IQ dimension in Jordan.

$\mathbf{H}_{2}$ : CS of the e-government system dimension will be affirmatively and significantly influenced by the IQ dimension in Jordan.

$\mathbf{H}_{3}$ : CIU of the e-government system dimension will be affirmatively and significantly influenced by the SVQ dimension in Jordan.

$\mathbf{H}_{4}$ : CS of the e-government system dimension will be affirmatively and significantly influenced by the SVQ dimension in Jordan.

H5: $C I U$ of the e-government system dimension will be affirmatively and significantly influenced by the $S Q$ dimension in Jordan.

H6: CS of the e-government system dimension will be affirmatively and significantly influenced by the SQ dimension in Jordan.

$\mathbf{H}_{7}$ : $P V-E G O V$ dimension will be affirmatively and significantly influenced by the CIU dimension in Jordan.

H8: $P V$-EGOV dimension will be affirmatively and significantly influenced by the CS dimension in Jordan.

H9: CIU dimension will be affirmatively and significantly influenced by Demographic variables (gender, age, and education) dimension in Jordan. 


\section{Research Methodology}

In order to realize the current research goals, the quantitative method was elected. The SEM approach was selected to attain several goals of current research such as: evaluating the factors influencing PV-EGOV in Jordan, obtaining the results of testing hypotheses, and evaluating the moderating role of Demographic variables on CIU of e-government in Jordan. The items of the construct were eventually developed to measure the level of PV-EGOV in Jordan from citizens' standpoints depending on Five points Likert scale where "strongly disagree" is the first point represents the low level of the PV-EGOV and "strongly agree" is the fifth point represents the highest level of the PV-EGOV. Table 1 shows the developed items of constructs of current research.

The last design of construct items was presented to the study sample in Arabic language after passing two stages of translation tasks which were performed by sending the invitation of translation form to three experts in language. After that, 20 citizens; who continuously perform their daily functions under the e-government system in Jordan; were invited to fill the first draft of the construction items. The results of this pilot study aimed to have grammatical items construct and originate the correct meaning of all items. Next, the current research adopted the electronic survey form to distribute the questionnaire for the targeted sample of e-government users in Jordan (Basarir-Ozel et al., 2017). Through this way, all items of the construct are responded without ignoring any item. In addition, the previous processes were executed with the guarantee of privacy matters, these steps have minified the prospect of threat of common method bias (Podsakoff et al., 2003). The stage of data collection was initiated in Jun 2021 and ended in July 2021.

Table 1

Adapted construct items

\begin{tabular}{lcl}
\hline Factor & No of items & References \\
\hline SQ & 3 & Wang \& Liao (2008), DeLone, \& McLean (2003), Wang et al. (2007) and Ozkan \& Koseler (2009) \\
IQ & 5 & Wang \& Liao (2008), Urbach et al. (2010), DeLone \& McLean (2003) and Wang et al. (2007) \\
SVQ & 5 & Wang \& Liao (2008), Balaban et al. (2013) and Chiu et al. (2007) \\
CIU & 4 & Wang \& Liao (2008), Lin, H. F. (2007), and Wang et al. (2007) \\
CS & 3 & Wang \& Liao (2008), and Wang et al. (2007) \\
PV-EGOV & 29 & Scott et al. (2016) \\
\hline
\end{tabular}

\section{Results}

AMOS program V.22 and SPSS software were declared to be employed for estimating the research hypotheses. Sequential steps of analysis were conducted through 1) SPSS techniques to prepare a data of the current study, 2) CFA approach to estimate the measurement model of our study, 3) SEM method to obtain the results of hypotheses (Bagozzi \& Yi, 1988; Hair et al., 2007; Kline, 2011).

\subsection{Demographic Variables Description}

The gender characteristic distribution of respondents in the current study was $51.2 \%$ male and $48.8 \%$ female. In addition, the age characteristic distribution of the current study sample reflected that the percentage of distribution was $6.9 \%$ in the range of $<30$ years, $36.5 \%$ in the range of $31-40$ years, $52.2 \%$ in the range of $41-50$ years and the remainder in the range of $>51$ years. Moreover, the Education characteristic distribution indicated distribution of the current study sample that the percentage of distribution was $8.2 \%$ has diploma or less than certifications, $48.1 \%$ has bachelor certifications, and $43.7 \%$ has post-graduate certifications. As provided in Fig. 1.

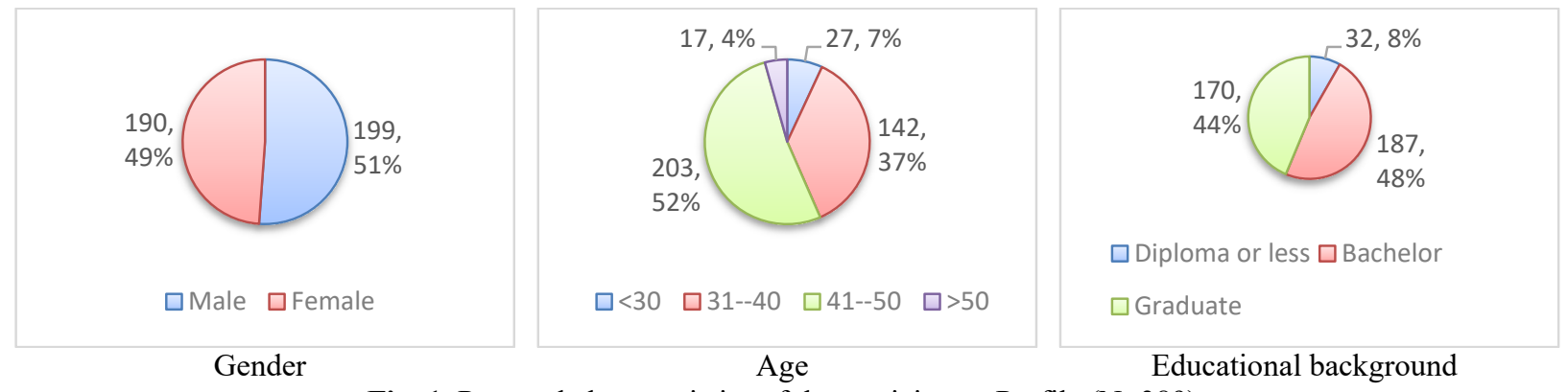

Fig. 1. Personal characteristics of the participants Profile $(\mathrm{N}=389)$

\subsection{Measurement of Research Model}

For having an adequate model fitting the current study, several statistical techniques were utilized to evaluate the measurement indices. According to (Hair, 2007; Kline, 2011; Newkirk \& Lederer, 2006), the measurement results of PV-EGOV model indicators were obviously signalized as a passable fit of the current research model. As can be clearly seen in Table 2. 
Table 2

Measurements of PV-EGOV model

\begin{tabular}{llllllll}
\hline construct & $\mathbf{x}^{2} / \mathbf{d f}$ & IFI & TLI & CFI & GFI & AGFI \\
\hline Initial & 2.569 & .916 & .908 & .916 & .765 & .733 \\
Final & 2.233 & .937 & .928 & .937 & .807 & .770 \\
Criteria values & $\mathrm{x}^{2} / \mathrm{df}<3$ & IFI $>.9$ & TLI $>.9$ & CFI $>.9$ & GFI $>.9$ & AGFI $>.9$ \\
\hline
\end{tabular}

As can be noticed in Table 3, the internal consistency of study constructs was accomplished by retrieving Cronbach's alpha value for each construct as its value should be greater than or equal to 0.7 (Hair et al., 2014). In addition, the loading values factor of each item was produced as an acceptable value should be greater than or equal to 0.6 (Creswell, 2009). Moreover, the composite reliability (CR) of each construct was conducted as an acceptable value that should be greater than or equal to 0.6 (Bagozzi \& Yi, 1988). In order to achieve convergent validity of the study construct, The Average Variance Extracted (AVE) was also computed as a reasonable value that should be greater than or equal to 0.5 (Bagozzi \& Yi, 1988). Some items were not extracted due to poor loading values (One item from the SQ construct and one item from the PV-EGOV construct). Consequently, the construct model of current research achieved a congruous internal consistency, and the discriminant validity was verified through computing the square root of AVE. As can be presented in Table 3.

Table 3

CFA standardized loading, AVE, CR.

\begin{tabular}{|c|c|c|c|c|}
\hline Factor & Items & FL & CR & AVE \\
\hline \multirow[t]{3}{*}{$\operatorname{SQ}(\alpha=.856)$} & SQ1 & 0.738 & \multirow[t]{3}{*}{0.809} & \multirow[t]{3}{*}{0.586} \\
\hline & SQ2 & 0.737 & & \\
\hline & SQ3 & 0.818 & & \\
\hline \multirow[t]{5}{*}{ IQ $(\alpha=.907)$} & IQ1 & 0.806 & \multirow[t]{5}{*}{0.896} & \multirow[t]{5}{*}{0.634} \\
\hline & IQ2 & 0.787 & & \\
\hline & IQ3 & 0.796 & & \\
\hline & IQ4 & 0.76 & & \\
\hline & IQ5 & 0.83 & & \\
\hline \multirow[t]{4}{*}{$\operatorname{SVQ}(\alpha=.891)$} & SV1 & 0.818 & \multirow[t]{4}{*}{0.868} & \multirow[t]{4}{*}{0.623} \\
\hline & SV2 & 0.74 & & \\
\hline & SV4 & 0.81 & & \\
\hline & SV5 & 0.787 & & \\
\hline \multirow[t]{3}{*}{ CIU $(\alpha=.831)$} & U1 & 0.85 & \multirow[t]{3}{*}{0.817} & \multirow[t]{3}{*}{0.536} \\
\hline & U2 & 0.85 & & \\
\hline & U3 & 0.636 & & \\
\hline \multirow[t]{3}{*}{$\operatorname{CS}(\alpha=.918)$} & US1 & 0.878 & \multirow[t]{3}{*}{0.918} & \multirow[t]{3}{*}{0.788} \\
\hline & US2 & 0.876 & & \\
\hline & US3 & 0.909 & & \\
\hline \multirow[t]{28}{*}{ PVEGOV $(\alpha=.976)$} & PVE1 & 0.681 & \multirow[t]{28}{*}{0.976} & \multirow[t]{28}{*}{0.589} \\
\hline & PVE2 & 0.696 & & \\
\hline & PVE3 & 0.706 & & \\
\hline & PVE4 & 0.71 & & \\
\hline & PVE5 & 0.709 & & \\
\hline & PVE6 & 0.808 & & \\
\hline & PVE7 & 0.749 & & \\
\hline & PVE8 & 0.758 & & \\
\hline & PVEE1 & 0.792 & & \\
\hline & PVEE2 & 0.842 & & \\
\hline & PVEE3 & 0.814 & & \\
\hline & PVEE4 & 0.816 & & \\
\hline & PVEE5 & 0.8 & & \\
\hline & PVEE6 & 0.792 & & \\
\hline & PVEE7 & 0.759 & & \\
\hline & PVEE8 & 0.824 & & \\
\hline & PVEE9 & 0.805 & & \\
\hline & PVS1 & 0.776 & & \\
\hline & PVS2 & 0.784 & & \\
\hline & PVS3 & 0.82 & & \\
\hline & PVS4 & 0.828 & & \\
\hline & PVS5 & 0.791 & & \\
\hline & PVS6 & 0.8 & & \\
\hline & PVS7 & 0.814 & & \\
\hline & PVS8 & 0.743 & & \\
\hline & PVS10 & 0.688 & & \\
\hline & PVS11 & 0.683 & & \\
\hline & PVS12 & 0.643 & & \\
\hline
\end{tabular}

The Pearson correlation, mean and standard deviation tests were generated for the factors of present study. As can be clearly seen in table 5 Information, service and SQ are affirmatively connected to CIU of e-government in Jordan $(r=.683, p<.01)$, $(\mathrm{r}=.844, \mathrm{p}<.01)$ and $(\mathrm{r}=.733, \mathrm{p}<.01)$ respectively. In addition, Information, service and system quality are affirmatively 
linked to CS of e-government in Jordan $(r=.860, p<.01),(r=.921, p<.01)$ and $(r=.858, p<.01)$ respectively. Finally, CIU and CS are positively conjugated to PV-EGOV in Jordan $(r=.576, \mathrm{p}<.01),(\mathrm{r}=.708, \mathrm{p}<.01)$ respectively.

Table 4

Person Correlations test

\begin{tabular}{llllll}
\hline & IU & SVQ & IQ & CS & SQ \\
\hline IU & 1 & & & & \\
SVQ & $.844^{* *}$ & 1 & & & \\
IQ & $.683^{* *}$ & $.964^{* *}$ & 1 & 1 & 1 \\
CS & $.795^{* *}$ & $.921^{* *}$ & $.860^{* *}$ & $.858^{* *}$ & $.946^{* *}$ \\
SQ & $.733^{* *}$ & $.948^{* *}$ & $.692^{* *}$ & $.708^{* *}$ & 1 \\
PVEGOV & $.576^{* *}$ & $.694^{* *}$ & & $.587^{* *}$ \\
\hline
\end{tabular}

**. Correlation is significant at the 0.01 level (2-tailed).

\subsection{Structural Model}

The evaluation processes of the structural model are considered as the last stage of analysis. In this section, the SEM was nominated to generate the hypotheses results of the current study and to determine the mediation role of demographic variables on CIU of e-government in Jordan. Through AMOS software V20, the SEM approach was proclaimed to be applied for generating the results of Coefficient Estimates (Beta), Standard Error, T-statistics, and P-value. The outcomes of current research declared that IQ has significantly and directly affected on CIU and CS of the e-government system in Jordan $(\beta=-$ $0.579, \mathrm{p}=0.000)$ and $(\beta=-0.357, \mathrm{p}=0.000)$ respectively; $\mathbf{H}_{\mathbf{1}}$ and $\mathbf{H}_{\mathbf{2}}$ provided empirical support. In addition, the results indicated that SVQ has significantly, directly, and affirmatively an impact on CIU and CS of e-government system in Jordan $(\beta=0.912, p=0.000)$ and $(\beta=1.711, p=0.000)$ respectively; $\mathbf{H}_{3}$ and $\mathbf{H}_{4}$ gained empirical evidence. Besides, SQ has not provided a significant impact on CIU e-government in Jordan where it has significantly and directly impacted on CS of e-government in Jordan $(\beta=-0.022, \mathrm{p}=0.013)$ and $(\beta=-0.233, \mathrm{p}=0.000)$ respectively; $\mathbf{H}_{5}$ did not provide empirical support and $\mathbf{H}_{6}$ gained empirical support. Moreover, the current research outcomes depicted that CIU and CS of E-government have significantly and directly supported an empirical impact on PV-EGOV in Jordan $(\beta=-1.818, p=0.000)$ and $(\beta=1.253, p=0.000)$ respectively; $\mathbf{H}_{7}$ and $\mathbf{H}_{8}$ gained empirical evidence. Finally, the outcomes of current research revealed that Demographic characteristics (gender, age, education) have not moderated the CIU of e-government in Jordan $(\beta=0.005, p=0.093),(\beta=-0.002$, $\mathrm{p}=0.330)$ and $(\beta=0.006, \mathrm{p}=.023)$ respectively; $\mathbf{H}_{9}$ did not provide empirical support. As can be remarked in Table 5 .

Table 5

Maximum Likelihood Estimates

\begin{tabular}{|c|c|c|c|c|c|}
\hline Independent Variables & dependent Variables & Coefficient Estimates(Beta) & Standard Error & T-statistics & $\mathrm{P}$ \\
\hline IQ & IU & -.579 & .014 & -42.349 & $* * *$ \\
\hline IQ & CS & -.357 & .080 & -4.440 & $* * *$ \\
\hline SVQ & IU & .912 & .015 & 61.390 & $* * *$ \\
\hline SVQ & $\mathrm{CS}$ & 1.711 & .090 & 19.052 & $* * *$ \\
\hline SQ & IU & .022 & .009 & 2.478 & .013 \\
\hline SQ & CS & -.233 & .058 & -4.049 & $* * *$ \\
\hline CIU & PVEGOV & -1.818 & .338 & -5.379 & $* * *$ \\
\hline $\mathrm{CS}$ & PVEGOV & 1.253 & .109 & 11.496 & $* * *$ \\
\hline CIU & Gender & .005 & .003 & 1.682 & .093 \\
\hline CIU & Age & -.002 & .002 & -.975 & .330 \\
\hline CIU & Education & .006 & .003 & 2.273 & .023 \\
\hline
\end{tabular}

\section{Discussion of results}

The major target of the current study is to identify and explore the potential factors affecting the PV-EGOV in Jordan through applying the update IS success model. Generally, the updated IS model considers a measurable construct to evaluate PVEGOV theory. Quality dimensions' support PV-EGOV in Jordan through the role of mediation effect of CIU and CS dimensions. Going through the current results, the present article has answered and confirmed the first research question "What is the role of the quality dimensions on PV-EGOV in Jordan". The article outcomes have particularly and empirically illuminated for responding and confirming the second article question "How do the CIU and CS dimensions mediate the relationship between quality dimensions and PV-EGOV in Jordan". Moreover, the article results have empirically responded to the third research question query "How do the demographic variables moderate CIU of e-government in Jordan". The results of the current article have indicated that empirical evidence was provided for most hypotheses which mean the updated IS model is considered as an adequate model to measure and evaluate the PV-EGOV in line with Agbabiaka, O. (2018). However, H5; which theorized that SQ will have an impact on the CIU of e-government in Jordan; has not gained empirical support. The potential interpretation for rejecting this theorized hypothesis is that the citizens may compare Jordan's e-government characteristics with several applications such as mobile applications, social media websites, and others. $\mathbf{H}_{9}$; which indicated that Demographic variables will have a moderation role on CIU of e-government; has not presented empirical support in line with prior studies (Abu-Shanab, 2021; Stefanovic, 2016). 
According to the results in table 6, the negative value of the coefficient estimate in the hypotheses reflects that the level of the dependent variable will be increased when the value of an independent variable is increased, otherwise, it will be decreased. For example, $\mathbf{H 1}$ theorized that IQ has affected the CIU with results $(\beta=-0.579, p=0.000)$; the level of the CIU effect will be increased when the level of IQ is high, otherwise, the CIU will be declined in the opposite results case.

\section{Managerial Implications, and Recommendations}

\subsection{Managerial Implications}

The recent article has contributed to the PV-EGOV domain from the citizens' perspective. The current research has empirically confirmed and asserted the prior theoretical studies that have claimed that the IS model could determine the PV-EGOV (Agbabiaka, O, 2018; Scott et al., 2016; Stefanovic et al., 2016). The results of the current article showed that the quality dimensions; except SQ on CIU; have a strong effect on PV-EGOV in Jordan through the mediating role of CS and CIU. The most important affecting dimension that impacted the PV-EGOV in Jordan is SVQ. However, the main feature of the current article from the previous studies is that our article has empirically embarked to evaluate the effect of IS model dimensions on the PV-EGOV. The research outcomes could be considered as a guide baseline for public institutions in Jordan. These institutions need to comprehensively have a better understanding of the determinants that affect the creating/increasing the PVEGOV in Jordan. Also, get a better understanding of the determinants that influence the PV-EGOV considers as critical key for developing, enhancing, and sustaining e-government technology. Creating or increasing the PV-EGOV in Jordan requires several serious decisions from public institutions such as top management support, increase citizens' awareness about e-government services for employees and public, serious willingness to reduce and eliminate the administration corruption in public institutions, and as Jordan a developing country, there are economic constraints due to the magnitude amount of the debt from the World Bank which leads to ignore in focusing and developing on any type of IS technology.

\subsection{Recommendations}

There is an agreement among different scholars, practitioners, and developers in the e-government domain that the social quality dimension might be an essential determinant to assess the PV-EGOV. Thus, we suggest that the trends of future related works could empirically examine the effect of social quality on e-government to create a public value. In addition, the citizens' participation in the designing phase of the presented e-government services is considered as a primary matter to gain their positive attitude about the e-government system. Thus, it is proposed to practically investigate the role of citizens' e-participant e-government services shaping, this could help the public institutions for creating/increasing / developing the PV-EGOV. Moreover, it is noticeable that the citizens' behavior is hard to be investigated due to a huge amount of IS applications. We believe that there is an engagement between the citizens' behavior in social media applications (especially social media addiction) and the e-government context. In addition, we believe that the top management support of public institutions in Jordan may play a major role in increasing the usability of e-government then increasing the benefit of e-government and generating public value. It is also recommended to investigate the role of top management support to increase awareness of employees and the public about the functions of e-government. Finally, the findings of current research cannot be generalized because it is just performed in Jordan's e-government context with a low number of citizens. Through this article, it is suggested to maximize the size of the sample and perform many studies in different sectors and countries.

\section{Acknowledgements}

The authors would like to express sincere gratitude to Mr. Muhammed Ahmed Qadri for his contributions in translating part of constructed items. Moreover, many thanks go to Mr. Mohammad Alnsour for his contributions to the editing process. In addition, many thanks go to valuable citizens' opinions about the e-government system in Jordan who freely shared their attitude in this research.

\section{References}

Abu-Shanab, E. A. (2021). Demographic Factors as Determinants of E-Government Adoption. In Recent Developments in Individual and Organizational Adoption of ICTs (pp. 60-81). IGI Global.

Abu-Shanab, E., \& Harb, Y. (2019). E-government research insights: Text mining analysis. Electronic Commerce Research and Applications, 38, 100892.

ADB. (2003) E-Government in the Asia and Pacific. The Governance in Brief, A Quarterly Publication Governance and Regional Cooperation Division Regional and Sustainable Development Department Issue 6-2003.

Agbabiaka, O. (2018, April). The Public Value Creation of eGovernment: An Empirical Study from Citizen Perspective. In Proceedings of the 11th International Conference on Theory and Practice of Electronic Governance (pp. 143-153).

Alabdallat, W. I. M. (2020). Toward a mandatory public e-services in Jordan. Cogent Business \& Management, 7(1), 1727620.

Alhanatleh, H. (2020). Assessing Open Source Software Success in Learning Management Systems Context in Jordan: Applied of an Integration of Technology Acceptance Model and Information Systems Success. International Journal of Scientific Research and Management. 8(10), 90-109.

Almarabeh, T., \& AbuAli, A. (2010). A general framework for e-government: definition maturity challenges, opportunities, and success. European Journal of Scientific Research, 39(1), 29-42. 
Alzghoul, A. (2013). Evaluation of University-Library knowledge management practice: comparative case studies from developing and developed countries.

Bagozzi, R. P., \& Yi, Y. (1988). On the evaluation of structural equation models. Journal of the academy of marketing science, 16(1), 74-94.

Balaban, I., Mu, E., \& Divjak, B. (2013). Development of an electronic Portfolio system success model: An information systems approach. Computers \& Education, 60(1), 396-411.

Basarir-Ozel, B., \& Mardikyan, S. (2017). Factors affecting E-commerce adoption: A case of Turkey. The International Journal of Management Science and Information Technology (IJMSIT), (23), 1-11.

Bryson, J. M., Crosby, B. C., \& Bloomberg, L. (2014). Public value governance: Moving beyond traditional public administration and the new public management.

Chiu, C. M., Chiu, C. S., \& Chang, H. C. (2007). Examining the integrated influence of fairness and quality on learners' satisfaction and Web-based learning continuance intention. Information systems journal, 17(3), 271-287.

Creswell, J. (2009). Research Design: Qualitative, Quantitative, and Mixed Methods Approaches, 3rd edition, . (3rd (ed.)). Thousand Oaks, Sage Publications.

DeLone, W. H., \& McLean, E. R. (1992). Information systems success: The quest for the dependent variable. Information systems research, 3(1), 60-95.

DeLone, W. H., \& McLean, E. R. (2003). The DeLone and McLean model of information systems success: a ten-year update. Journal of management information systems, 19(4), 9-30.

Ha, T. T. (2016). Empirically testing the public value based conceptual framework for evaluating e-government performance in Vietnam. Modern Economy, 7(02), 140.

Hair, J. F., Money, A. H., Samouel, P., \& Page, M. (2007). Research methods for business. Education+ Training.

Hair, J. F., Black, W. C., Babin, B. J., \& Anderson, R. E. (2014). Multivariate data analysis: Pearson new international edition. Essex: Pearson Education Limited, 1(2).

Harrison, T. M., Guerrero, S., Burke, G. B., Cook, M., Cresswell, A., Helbig, N., ... \& Pardo, T. (2012). Open government and e-government: Democratic challenges from a public value perspective. Information Polity, 17(2), 83-97.

Idoughi, D., \& Abdelhakim, D. (2018). Developing Countries E-Government Services Evaluation Identifying and Testing Antecedents of Satisfaction Case of Algeria. International Journal of Electronic Government Research (IJEGR), 14(1), 63-85.

Khaddam, A. A., Alzghoul, A., Abusweilem, M. A., \& Abousweilem, F. (2021). Business intelligence and firm performance: a moderated-mediated model: 商业智能与企业绩效：一种适度的中介模型. The Service Industries Journal, 1-17.

Kline, R.B. (2011). Principles and Practice of Structural Equation Modeling. In The Guilford Press (2nd ed.). The Guilford Press.

Li, L., Du, K., Xin, S., \& Zhang, W. (2017). Creating value through IT-enabled integration in public organizations: A case study of a prefectural Chinese Center for Disease Control and Prevention. International Journal of Information Management, 37(1), 1575-1580.

Lin, H. F. (2007). Measuring online learning systems success: Applying the updated DeLone and McLean model. Cyberpsychology \& behavior, 10(6), 817-820.

Mensah, I. K., Luo, C., \& Abu-Shanab, E. (2021). Citizen Use of E-Government Services Websites: A Proposed E-Government Adoption Recommendation Model (EGARM). International Journal of Electronic Government Research (IJEGR), 17(2), 19-42.

Mirchandani, D. A., Kathawala, Y. A., Jr, J. H. J., Hayes, J. P., \& Chawla, S. (2018). A comparison of perspectives of Kuwaiti and Indonesian residents towards e-government. Electronic Government, an International Journal, 14(2), $134-159$.

Nawafleh, S. (2018). Factors affecting the continued use of e-government websites by citizens: An exploratory study in the Jordanian public sector. Transforming Government: People, Process and Policy.

Newkirk, H. E., \& Lederer, A. L. (2006). The effectiveness of strategic information systems planning under environmental uncertainty. Information \& Management, 43(4), 481-501.

Nkanata, M. G. (2019, September). Applying DeLone and McLean information systems success model in the evaluation of e-government initiatives: a literature review. In Proceedings of 20th Annual IS Conference (Vol. 18, p. 287).

Ozkan, S., \& Koseler, R. (2009). Multi-dimensional students' evaluation of e-learning systems in the higher education context: An empirical investigation. Computers \& Education, 53(4), 1285-1296.

Pang, M. S., Lee, G., \& DeLone, W. H. (2014). IT resources, organizational capabilities, and value creation in public-sector organizations: a public-value management perspective. Journal of Information Technology, 29(3), 187-205.

Podsakoff, N. P. (2003). Common method biases in behavioral research: a critical review of the literature and recommended remedies. Journal of Applied Psychology, 885(879), 10-1037.

Petter, S., DeLone, W., \& McLean, E. R. (2013). Information systems success: The quest for the independent variables. Journal of management information systems, 29(4), 7-62.

Sami, A., Jusoh, A., Nor, K. M., Irfan, A., \& Qureshi, M. I. (2018). Systematic review of public value. Journal of Public Value and Administrative Insight, 1(1), 1-6.

Scott, M., DeLone, W., \& Golden, W. (2016). Measuring eGovernment success: a public value approach. European Journal of Information Systems, 25(3), 187-208.

Sharma, S. K., Al-Shihi, H., \& Govindaluri, S. M. (2013). Exploring quality of e-Government services in Oman. Education, Business and Society: Contemporary Middle Eastern Issues. 
Solli-Sæther, H. (2010, October). Analytical framework for e-government interoperability. In eChallenges e-2010 Conference (pp. 1-9). IEEE.

Stefanovic, D., Marjanovic, U., Delić, M., Culibrk, D., \& Lalic, B. (2016). Assessing the success of e-government systems: An employee perspective. Information \& Management, 53(6), 717-726.

Sterrenberg, G. (2016). Measuring IS success of e-government: A Case Study on the Disability Sector in Australia.

Suh, H., Chung, S., \& Choi, J. (2017). An empirical analysis of a maturity model to assess information system success: a firmlevel perspective. Behaviour \& information technology, 36(8), 792-808.

Nam, T. (2014). Determining the type of e-government use. Government information quarterly, 31(2), 211-220.

Twizeyimana, J. D., \& Andersson, A. (2019). The public value of E-Government-A literature review. Government information quarterly, 36(2), 167-178.

Urbach, N., Smolnik, S., \& Riempp, G. (2010). An empirical investigation of employee portal success. The Journal of Strategic Information Systems, 19(3), 184-206.

Wang, W. T., \& Wang, C. C. (2009). An empirical study of instructor adoption of web-based learning systems. Computers \& Education, 53(3), 761-774.

Wang, Y. S., \& Liao, Y. W. (2008). Assessing eGovernment systems success: A validation of the DeLone and McLean model of information systems success. Government information quarterly, 25(4), 717-733.

Wang, Y. S., Wang, H. Y., \& Shee, D. Y. (2007). Measuring e-learning systems success in an organizational context: Scale development and validation. Computers in Human Behavior, 23(4), 1792-1808. 
(C) 2022 by the authors; licensee Growing Science, Canada. This is an open access article distributed under the terms and conditions of the Creative Commons Attribution (CC-BY) license (http://creativecommons.org/licenses/by/4.0/). 